Ethiopian Journal of Environmental Studies \& Management 7(6): 635 - 644, 2014.

ISSN:1998-0507

doi: http://dx.doi.org/10.4314/ejesm.v7i6.6

Submitted: July 14, 2014

Accepted: October 06, 2014

\title{
TRACE METAL LEVELS OF DRINKING WATER SOURCES IN PARTS OF OSUN STATE, NIGERIA
}

\author{
ODEBUNMI, E.0., ${ }^{1}$ OLUTONA, G.0., ${ }^{2}$ AKINTUNDE, E.A., ${ }^{2}$ FABORO, E.0., ${ }^{2}$ BALOGUN, $0 . S .{ }^{3}$ AND \\ *OLUWANIYI, 0.0.1 \\ ${ }^{1}$ Department of Chemistry, University of Ilorin, Nigeria \\ ${ }^{2}$ Department of Chemistry and Industrial Chemistry, Bowen University, Iwo, Nigeria \\ ${ }^{3}$ Department of Chemistry, Obafemi Awolowo University, Ile-Ife, Nigeria
}

\begin{abstract}
This study was carried out to investigate the portability of drinking water sources available to people in parts of Osun State, Nigeria, especially with respect to trace metal levels. The trace metal contents were determined over a period of six months covering both the rainy and dry seasons. Tap, well, stream and borehole water from five towns (Osogbo, Iwo, Ejigbo, Ile-Ife and Ilesha) in Osun State were analysed using Atomic Absorption Spectrophotometer. The concentrations of the metals analyzed range $(\mu \mathrm{g} / \mathrm{mL})$ as follows: Fe (0.18-0.30), $\mathrm{Mn}$ (0.33-0.37), $\mathrm{Zn}$ (0.11-0.14), Cu (0.05-1.0), Pb (0.01-0.03), Hg (Nd-0.03), As (Nd-0.03), Cd (Nd-0.04), Cr (0.02$0.05)$, and $\mathrm{Ni}(0.02-0.05)$ while the mean levels $(\mathrm{ug} / \mathrm{mL})$ were of the order: $\mathrm{Hg}(0.01)<\mathrm{Pb}(0.02)$ $=\mathrm{As}(0.02)=\mathrm{Cd}(0.02)<\mathrm{Ni}(0.03)<\mathrm{Cr}(0.04)<\mathrm{Cu}(0.08)<\mathrm{Zn}(0.13)<\mathrm{Fe}(0.25)<\mathrm{Mn}(0.36)$. The results indicated a significant correlation in the metal contents of the water samples from the various locations as well as the various water sources. The trace metals contents ( $\mathrm{Fe}, \mathrm{Mn}, \mathrm{Zn}$, $\mathrm{Cu}, \mathrm{Cr}$ and $\mathrm{Ni}$ ) were below or equal to the limits set by WHO for drinking and domestic water while the toxic metals ( $\mathrm{Pb}, \mathrm{Hg}$, As and $\mathrm{Cd}$ ), recorded values higher than the safe limits set by WHO hence, the water sources are capable of constituting serious health hazards.
\end{abstract}

Key Words: $\quad$ Trace Metals, Water, Borehole, Well, Stream, Tap, Toxicity

\section{Introduction}

Water has maintained a status of being one of the most essential commodities on earth owing to its indispensable roles for agricultural and household use; industrial, tourism and cultural purposes; and as a medium for numerous biochemical and physiochemical reactions (Oyekunle et al., 2012).

According to WHO (2004), as of 2002, 1.1 billion people, representing $17 \%$ of the global population, were without safe drinking water and forecast has shown that more than
$47 \%$ of the global population will face severe water hardship by 2030 (Robert, 2008).

Nigeria is endowed with about 267 billion cubic metres of surface water and about 52 billion cubic metres of ground water annually (Ince et al., 2010). Generally, the quality of ground water in Nigeria is better than that of surface water in terms of health criteria, but much of the ground water is corrosive, and some have iron, nitrate or fluoride concentration above WHO guideline values (Ince et al., 2010). In spite of the generous endowment of surface and groundwater, which are capable of meeting

*Corresponding Author: Oluwaniyi, O.O.

Email: oluwaniyi@unilorin.edu.ng 
demands, the average national water supply coverage was only about $57 \%$ (about $60 \%$ for urban areas, $50 \%$ for semi-urban areas and $55 \%$ for rural areas) (Ince et al., 2010). Two of the major problems that are contended with in Nigeria are the insufficient quantity (source and amount) and poor quality of water (Adeniyi, 2004) and these are problems experienced in most cities and nations in the developing nations not to mention their rural settings (Oluyemi et al., 2010).

The poor state of the water and sanitation in Nigeria is reflected in the high infant mortality and morbidity rates for the country (Ince et al., 2010) which are mainly caused by malaria, diarrhoea and acute respiratory infections, all of which are related to unclean and inadequate sanitation. Together with typhoid, these diseases account for more than $70 \%$ of all child mortality and morbidity in Nigeria (Ince et al., 2010). In 1997, the World Health organization (WHO) reported that $40 \%$ of deaths in developing nations occur due to infections from water related diseases. Desirable quality of drinking water must be ensured in terms of levels of chemical and biological contaminants such as trace heavy metals, $\mathrm{pH}$, organic matters and pathogens (WHO, 2011).

Elevation in the trace metal contents of an aquatic system may arise from daily human activities, various degrees of geochemical reactions occurring in the sub-surface of the earth, runoff addition, aerial deposition and percolation-related phenomena (Ibe and Duruike, 2005). Among the possible contaminants of water, heavy metals have attracted an unprecedented attention owing to their high toxicities even at low concentrations.

\begin{tabular}{llllll}
\multicolumn{6}{l}{ Table 1: Senatorial district spread and the types of water sampled for trace metal analysis } \\
\hline $\begin{array}{l}\text { Senatorial } \\
\text { District }\end{array}$ & Boreholes & Stream & Tap & Well & $\begin{array}{l}\text { Total sample } \\
\text { per area }\end{array}$ \\
\hline Osun West & 2 & 2 & & & 8 \\
Osun Central & 2 & 2 & 2 & 2 & 8 \\
State Capital & 1 & 1 & 1 & 2 & 4 \\
Total & 5 & 5 & 5 & 5 & 20 \\
\hline
\end{tabular}

The major sources of water in major towns and cities of Osun state Nigeria is ground water (borehole and well), and sometimes streams and rivers especially during the dry season. These water sources are the alternatives to the inconsistent flow of pipe borne water, which would have been the more reliable source of safe water for the growing population (Oluyemi et al., 2010).

This study therefore aims at investigating the portability of drinking water sources available to the people in various parts of Osun State, Nigeria, with respect to trace metal levels with the view to constantly monitor the river and ground water quality in the state so as to record any alteration in the quality, which may lead to outbreak of health disorder or serious health effect.

\section{Materials and Methods Study area}

Drinking water samples were collected from four different sources (borehole, tap, well and stream) in five different locations in Osun State. Samples were collected from the State capital (Osogbo, $7^{\circ} 46^{\prime} \mathrm{N} 4^{\circ} 33^{\prime} \mathrm{E}$ ) and from two towns each from two of the three senatorial districts of Osun State - Osun West (Iwo, $7^{\circ} 38^{\prime} \mathrm{N} 4^{\circ} 11^{\prime} \mathrm{E}$ and Ejigbo, $7^{\circ} 54^{\prime} \mathrm{N} 4^{\circ} 19^{\prime} \mathrm{E}$ ) and Osun Central (Ile-Ife, $7^{\circ} 27^{\prime} \mathrm{N}, 4^{\circ} 34^{\prime} \mathrm{E}$ and Ilesa, $7^{\circ} 36^{\prime} \mathrm{N} 4$ 34' E). Samples were collected from these locations taking into consideration the population density and human activities in each particular area. Table 1 shows the senatorial district distribution of the four sources of water sampled for the trace metal analysis. The sampled water was from a mix of government and private properties. All of the sampled water was the main source of drinking water for the local population. 


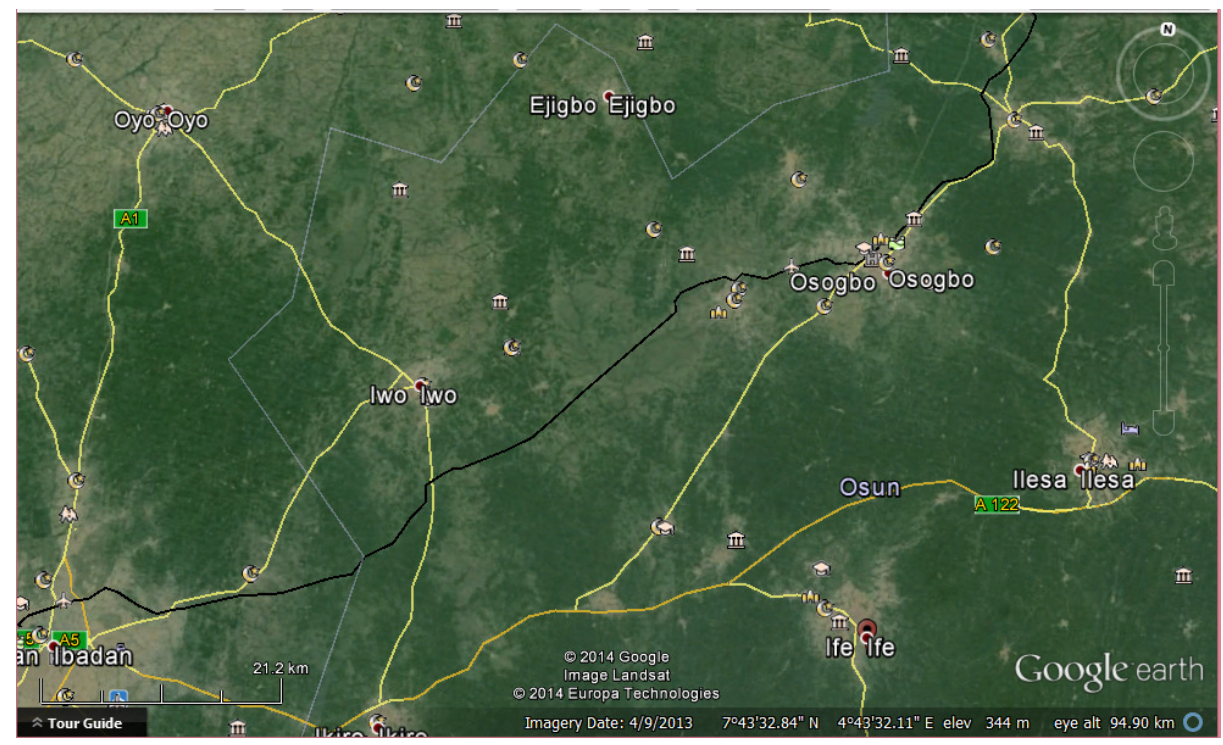

Figure 1: Map of Sampling Locations

The sampling was carried out over a period of six months, spanning the dry and wet seasons of 2009 and 2010. Samples were collected in November and December 2009 and January 2010, representing the dry season; and April, June and July 2010, representing the wet season.

\section{Sample Collection}

Samples for water quality studies were collected in $2 \mathrm{~L}$ plastic bottles that had been previously soaked in $10 \%$ nitric acid for 48 hrs, and rinsed with distilled water. The container was rinsed three times on site with the sample water before collecting the water sample for water quality analysis. All samples were filtered with cellulose acetate filters and stored immediately in a cooler, in order to ensure that the physical properties of the water samples were maintained, and transported to the laboratory where they were stored in the refrigerator prior analysis.

\section{Sample Digestion for Total Metal Determination}

A $50 \mathrm{~mL}$ aliquot of water sample was transferred into Teflon beaker and $5 \mathrm{~mL}$ of concentrated $\mathrm{HNO}_{3}$ was added. This was followed by gentle boiling on a thermostated hot plate in a fume cupboard for about 45 min. The digested samples were quantitatively transferred into a $25 \mathrm{~mL}$ volumetric flask and diluted to volume with double distilled water. From this, an aliquot was taken for AAS analysis.

\section{Quantification Process}

Trace metal concentrations in the drinking water samples were determined using a Buck Model 205 Flame Atomic Absorption Spectrophotometer from East Norwalk, United States of America.

\section{Recovery Analysis}

This was conducted to assess the error levels arising from contamination and adsorption losses in the speciation procedure and also to ascertain the precision of the analytical procedures used in this study. A 25 $\mathrm{mL}$ water sample was put into a Teflon beaker and was spiked with $25 \mathrm{~mL}$ of 50 $\mu \mathrm{g} / \mathrm{mL}$ of the metals and digested as earlier described. The digested spiked sample was made up to the mark in a $25 \mathrm{~mL}$ volumetric flask with doubly distilled water. Also, 25 $\mathrm{mL}$ each of $50 \mu \mathrm{g} / \mathrm{mL}$ of the standard heavy metal solution mixture was taken for analysis. The levels of these metals in the two samples were determined using the AAS. The percentage recovery $(\% \mathrm{R})$ for each metal was calculated using the relationship: 


$$
\% \mathrm{R}=\frac{\mathrm{A}-\mathrm{B}}{\mathrm{C}} \times 100
$$

where $\mathrm{A}=$ concentration of a metal in the spiked sample; $\mathrm{B}=$ concentration of a metal in the unspiked sample; and $\mathrm{C}=$ the amount of metal (ppm) used for spiking.

\section{Statistical Analysis of Data}

The mean and standard deviation for the metals from three replicate measurements, as well as the correlation matrix were determined using statistical package for social sciences (SPSS) software. Coefficient of variation was adopted to evaluate the intraand inter-state temporal variability of the metals.

\section{Results and Discussion}

The result of the recovery analysis of metal analysed for water samples drawn from all the five locations are presented in Table 2 below. Under the experimental conditions used, the standard calibration curves obtained showed high linearity level with $\mathrm{r}^{2}$ values between 0.9585 for $\mathrm{Pb}$ and 0.9973 for $\mathrm{Ni}$. Recoveries of trace metals in water ranged from $84.72 \pm 4.02 \%$ for $\mathrm{Hg}$ to $98.38 \pm 6.97 \%$ for $\mathrm{Zn}$. These values are adjudged acceptable, and hence, the results obtained are reliable.

Table 2: Value of recovery analysis and calibration curve

\begin{tabular}{|l|l|l|l|l|l|l|l|l|l|l|}
\hline & $\mathrm{Fe}$ & $\mathrm{Mn}$ & $\mathrm{Zn}$ & $\mathrm{Cu}$ & $\mathrm{Pb}$ & $\mathrm{Hg}$ & $\mathrm{As}$ & $\mathrm{Cd}$ & $\mathrm{Cr}$ & $\mathrm{Ni}$ \\
\hline $\mathrm{r}^{2}$ & 0.9961 & 0.9898 & 0.9896 & 0.9794 & 0.9585 & 0.9856 & 0.9987 & 0.9975 & 0.9892 & 0.9973 \\
\hline$\%$ & $87.50 \pm$ & $89.73 \pm$ & $98.38 \pm$ & $96.23 \pm$ & $86.99 \pm$ & $84.72 \pm$ & $92.88 \pm$ & $92.99 \pm$ & $89.15 \pm$ & $93.20 \pm$ \\
$\mathrm{R}$ & 6.60 & 6.31 & 6.97 & 3.06 & 3.53 & 4.02 & 3.54 & 4.55 & 3.97 & 3.91 \\
\hline
\end{tabular}

$*$ Value $=$ mean of triplicate analysis \pm s.d.

The mean total trace metal levels $(\mu \mathrm{g} / \mathrm{mL})$ for the water samples are presented in Table 3. The total metal concentrations were of the order: Iwo $(0.76)<$ Ile-Ife $(0.83)$ $<$ Ejigbo (0.89) < Osogbo (1.14) < Ilesa (1.23). The high metal load observed at Ilesa could be as a result of anthropogenic and industrial input, in addition to geochemical composition of the underlying rocks of the area, which might possibly contain some of the metals assessed (Aiuppa et al., 2003).

The six months mean metal content for all the four sources of water $(\mu \mathrm{g} / \mathrm{mL})$ was of the order: $\mathrm{Hg}(0.01)<\mathrm{Pb}(0.02)=\mathrm{As}(0.02)$ $=\mathrm{Cd}(0.02)<\mathrm{Ni}(0.03)<\mathrm{Cr}(0.04)<\mathrm{Cu}$ $(0.08)<\mathrm{Zn}(0.13)<\mathrm{Fe}(0.25)<\mathrm{Mn}(0.36)$. The concentrations of these trace metals were below the WHO recommended limits for drinking water with exception of $\mathrm{Pb}, \mathrm{Hg}$, As and $\mathrm{Cd}$ that were slightly above the recommended limit for drinking water by WHO (2011).
Table 4 represents the mean of the concentrations of metals in different water samples. The concentrations of the metals $(\mu \mathrm{g} / \mathrm{mL})$ range as follows: Fe $(0.18-0.30)$, $\mathrm{Mn}$ (0.33-0.37), Zn (0.11-0.14), Cu (0.05$1.0), \mathrm{Pb}(0.01-0.03), \mathrm{Hg}$ (Nd-0.03), As (Nd$0.03), \mathrm{Cd}(\mathrm{Nd}-0.04), \mathrm{Cr}(0.02-0.05)$, and $\mathrm{Ni}$ (0.02-0.05).

Concentration of $\mathrm{Fe}$ in all the water sources was generally below the WHO maximum permissible limit except stream water which was exactly equal to the recommended limit. The high concentration of the element in the stream might be due to direct release of domestic waste from anthropogenic activities and vehicular exhaust.

The Fe levels in this study were lower than the $31.78 \pm 0.80 \mu \mathrm{g} / \mathrm{mL}$ (river) levels reported by Oluyemi et al. (2010) for the Ife North Local Government area of Osun State. The highest level of $\mathrm{Mn}(0.40 \mu \mathrm{g} / \mathrm{mL})$ was recorded in the stream. This value was 
equivalent to the maximum recommended level by WHO (2011) while all others sources were lower than this limit. The result obtained in this study was lower than the value $(11.32 \mu \mathrm{g} / \mathrm{mL})$ reported for stream water by Oluyemi et al. (2010) or $76.79 \pm 12.89 \mu \mathrm{g} / \mathrm{mL}$ reported by Oyekunle et al. (2012) for the groundwater of Ile-Ife. On the other hand, Nsi and Ogori (2005) reported $0.005-0.0055 \mathrm{mg} / \mathrm{L}$ levels for well water and $0.15 \mathrm{mg} / \mathrm{L}$ for borehole waters of Markurdi, which are lower than what is being reported in this study. Mn toxicity constitutes a serious health hazard, resulting in severe pathological disorder of the central nervous system (Keen \& Ziderberg-Cherr, 1996). The toxicity can be manifested by a permanent crippling neurological disorder of the extra pyramidal system similar to Parkinson's diseases. In its milder form, the toxicity is expressed by aggressiveness, hallucinations, disturbances of libido and improper coordination (Oyekunle et al., 2012).

The $\mathrm{Zn}$ concentration ranges from 0.11 (well) to $0.14 \mu \mathrm{g} / \mathrm{mL}$ (stream). These values were lower than the $147.3 \pm 30.4$ $\mu \mathrm{g} / \mathrm{mL}$ (hand dug well) and 6.19 $\pm 0.24 \mu \mathrm{g} / \mathrm{mL}$ (stream) levels reported by Oluyemi et al., (2010) and $31.86 \pm 3.64 \mu \mathrm{g} / \mathrm{mL}$ reported for groundwater by Oyekunle et al. (2012) for Ife North LGA and Ife Township respectively. However, the values were much higher than the $0.04 \pm 0.06 \mu \mathrm{g} / \mathrm{mL}$ reported for Ojota area in Lagos (Oyeku and Eludoyin, 2010). These variations may have resulted from the geological differences of the areas (Oyekunle et al., 2012). $\mathrm{Zn}$ is an essential element required for life processes of various enzymes (Wordstron, 1982). It also interferes at different levels in the endocrine system and lipid and carbohydrate metabolism. Acrodermatitis enterohepatica is a disease characterised by low serum zinc and at elevated levels, $\mathrm{Zn}$ may be carcinogenic (Schwartz, 1975). Zn deficiency symptoms include nausea, dizziness, gastric ulcers, lethargy, muscle pain, impairment of immune function, headaches, vomiting, dehydration, stomach aches, poor muscle coordination, fatigue, fever, depression, malaise, cough, possible renal failure and increased blood level of insulin-like growth factor and testosterone, both of which are related to prostate cancer (Michael and Stanford, 2003; Bacha et al., 2010). Histopathology signs of $\mathrm{Zn}$ poisoning, including fibrosis and vacuolization were associated with elevated pancreatic $\mathrm{Zn}$ concentration (Van der Merwe et al., 2011).

$\mathrm{Cu}$ is an essential trace metal to human life at moderate levels, functioning as part of several enzymes such as tyrosine, cytochrome oxidase, super oxide dismutase, amine oxidases and uricase (Oyekunle et al., 2012). The mean concentrations of $\mathrm{Cu}$ in this study range from 0.11 (stream) to 1.00 $\mu \mathrm{g} / \mathrm{mL}$ (borehole). The values of $\mathrm{Cu}$ in all water sources analysed were lower than the permissible limit set by WHO (2011). Oyekunle et al. (2012) reported a higher $\mathrm{Cu}$ content $(8.28 \pm 0.91 \mu \mathrm{g} / \mathrm{mL})$ in the underground water of Ile-Ife. The value of $\mathrm{Cu}$ obtained for borehole in this study was similar to the value of $1.16 \pm 0.05 \mathrm{mg} / \mathrm{L}$ obtained for borehole in Ife North LGA of Osun State but the hand dug well recorded values lower than the $46.35 \pm 0.07 \mathrm{mg} / \mathrm{L}$ reported for hand dug well by Oluyemi et al., (2010). The level in underground water (borehole and well) reported in this study was higher compared to stream and tap water. Geochemical environment might have been responsible for the levels of $\mathrm{Cu}$ detected in the water samples while anthropogenic inputs could not have seriously impacted the underground waters of the studied areas (Oyekunle et al., 2012).

Lead is a highly toxic naturally occurring metal that have been present in soils, surface waters and groundwater (Olutona et al., 2012). The levels of $\mathrm{Pb}$ range from 0.01 (tap water) to 0.03 (borehole and stream). These 
findings were low compared to $0.18 \pm 0.04$ $\mu \mathrm{g} / \mathrm{mL}$ obtained in underground water of IleIfe by Oyekunle et al. (2012); 4.01 \pm 3.82 $\mu \mathrm{g} / \mathrm{mL}, 4.9 \pm 0.18 \mu \mathrm{g} / \mathrm{mL}$, and $2.4 \pm 3.3 \mu \mathrm{g} / \mathrm{mL}$ $\mathrm{Pb}$ levels respectively reported for the underground water resources from Ife North Local Government area, Ibadan and Lagos by Oluyemi et al. (2010) and Oyeku and Eludoyin (2010). The values of $\mathrm{Pb}$ in different water sources obtained in this study was higher than WHO (2011) recommended limit except tap water that has equivalent amount to the recommended limit of 0.01 $\mathrm{mg} / \mathrm{L}$. Elevated $\mathrm{Pb}$ levels of groundwater may be an indication of surface pollution resulting from the several years of automobile combustion of petrol containing organolead additives in the past, unguarded disposal of used lead-acid batteries, alloys, soldering metal and uninformed open air incineration of waste material at dump sites (Oyekunle et al., 2012). All these anthropogenic activities have tendency to increase the metal contents of underground water resources via percolation related phenomena if the $\mathrm{Pb}$ or its related compounds become soluble at lower $\mathrm{pH}$ levels (Oyekunle et al., 2012). $\mathrm{Pb}$ can cause serious health problems, especially for infants, children and pregnant women (Oyekunle et al., 2012). Acute and chronic effects of $\mathrm{Pb}$ poisoning include psychosis (Okunola et al., 2011). $\mathrm{Pb}$ poisoning also have ill-defined symptoms such as nausea, vomiting, abdominal pains, anorexia, constipation, insomnia, anaemia, irritability, mood disturbance and coordination loss (Grandjean and Nielson, 1979). In blood, $\mathrm{Pb}$ concentrations of less than $10 \mu \mathrm{g} / \mathrm{dL}$ in children and adolescents can cause cognitive defects (Wu et al., 2003). $\mathrm{Pb}$ effects especially on the foetus and children may include behavioural changes and impaired performance in IQ tests (Fatoki et al., 2003).

Elemental mercury is basically released from industrial, agricultural, household, commercial and medicinal products containing mercury, sewage discharge and soil. Inorganic mercury is found in batteries used in cars, mechanical and chemical industries. Inorganic mercury is the most common form that is present in drinking water but is not considered to be very harmful to human health, in terms of the levels found in drinking water. Inorganic mercury compounds are rapidly accumulated in the kidney; about $7-8 \%$ of ingested mercury in food is absorbed (WHO, 2005a). Absorption from water may be $15 \%$ or less depending on the compound (IPCS, 1990). In this study, the levels of $\mathrm{Hg}$ ranged from 0.00 in tap water to $0.03 \mu \mathrm{g} / \mathrm{mL}$ in stream water. The levels of $\mathrm{Hg}$ obtained from borehole, stream and well water sources were higher than the $0.006 \mu \mathrm{g} / \mathrm{mL}$ recommended for drinking water by WHO (2011).

Arsenic (As) can be found in traces in nature. Elevated levels can be found naturally in groundwater which may be as a result of contamination caused by hazardous waste or industries that make use of As. Elevated levels of arsenic in drinking water may cause thickening and discolouration of skin, nausea, vomiting, diarrhoea, numbness in the hand and feet (Farrell-Poe, 2010). In this study, arsenic was not detected in tap water but levels of arsenic in all other sources of water were higher than the recommended WHO limit of $0.01 \mu \mathrm{g} / \mathrm{mL}$. Concentration of arsenic is generally higher in groundwater than surface water which may be as a result of the dissolution of naturally occurring Ascontaining minerals.

Cadmium is a modern toxic metallic environmental pollutant. With exception of tap water where $\mathrm{Cd}$ was not detected, all other sources of water had values higher than the recommended level of $0.003 \mathrm{mg} / \mathrm{L}$ by WHO (2011). By comparison, the values of $\mathrm{Cd}$ in various water sources in this study were lower than the values $0.08-0.11 \mu \mathrm{g} / \mathrm{mL}$ and $0.98 \pm 0.67 \mu \mathrm{g} / \mathrm{mL}$ reported (Oyekunle et 
al., 2012; Oluyemi et al., 2010) for Ife North Local Government area and Ife township. The high level of $\mathrm{Cd}$ in the various water samples, with exception of tap water, could be as a result of its long anthropogenic inputs which leached into the stream and the underground waters from contaminated sites. $\mathrm{Cd}$ has mutagenic, carcinogenic and tetratogenic effects (Goyer and Clarkson, 2001) and is toxic to humans at extremely low levels (Okunola et al., 2011). Prolonged exposure to the metal may result in mental dysfunction, characterised by tubular proteinuria. Exposure to high concentration of $\mathrm{Cd}$ leads to obstructive lung disease and $\mathrm{Cd}$ pneumonitis, which is characterized by chest pain, cough with foamy and bloody sputum, and death of the lung tissues lining because of excessive accumulation of water fluids (Okunola et al., 2011).

$\mathrm{Cr}$ as a common contaminant is usually encountered in the environment in two oxidation states, $\mathrm{Cr}(\mathrm{III})$ and $\mathrm{Cr}(\mathrm{VI})$. $\mathrm{Cr}(\mathrm{III})$ is considered as an essential micro nutrient for human, plant and animal metabolism (Rafati et al., 2010; Patil and Ahmad, 2011) while $\mathrm{Cr}(\mathrm{VI})$ is very soluble and hazardous to health (Rafati et al., 2010). The values of $\mathrm{Cr}$ from different water sources in this study were lower than the recommended limit by WHO (2011) with exception of stream which was equivalent to the recommended limit (Table 4).

The primary source of nickel in drinking water is leaching from metals in contact with drinking water, such as pipes and fittings. However, nickel may also be present in some groundwater sources as a consequence of dissolution from ore-bearing nickel (WHO, 2005b). The levels of nickel in this study range from $0.02 \mu \mathrm{g} / \mathrm{mL}$ (tap) to $0.05 \mu \mathrm{g} / \mathrm{mL}$ (stream). In all the water sources, the concentration of nickel was lower than the $0.07 \mathrm{mg} / \mathrm{L}$ maximum permissible level (WHO, 2011). Nickel concentrations in groundwater depend on the soil use, $\mathrm{pH}$ and depth of sampling (WHO, 2005b). This could be the reason why the concentration of $\mathrm{Ni}$ in borehole is slightly higher than well water (Table 4). High concentration of $\mathrm{Ni}$ in stream water could be due to the 'stainless' materials used in households and metal industries been eroded into the stream as a result of dumping waste.

\section{Conclusions}

Results obtained from this study revealed that the metals analysed were found mostly within the WHO limits (WHO, 2011). Few exceptions were observed in $\mathrm{Pb}, \mathrm{Hg}$, As and $\mathrm{Cd}$ which were found to be a little above the set standard. The users of these untreated sources of water from the study area may suffer from several heavy metal-induced toxicity symptoms. It is therefore recommended that the waters should be subjected to further treatment that will reduce drastically, the levels of the few trace metals identified that may pose serious health hazards to the society. 
Table 3: Mean levels $(\mu \mathrm{g} / \mathrm{mL})$ of trace metals in water sources for different Cities in parts of Osun State, Nigeria

\begin{tabular}{|c|c|c|c|c|c|c|c|c|c|c|c|c|}
\hline & $\mathrm{Fe}$ & Mn & $\mathrm{Zn}$ & $\mathrm{Cu}$ & $\mathrm{Pb}$ & $\mathrm{Hg}$ & As & $\mathrm{Cd}$ & $\mathrm{Cr}$ & $\mathrm{Ni}$ & $\begin{array}{l}\text { Total Metal } \\
\text { burden }\end{array}$ & $\begin{array}{l}\text { Correlation } \\
\text { matrix }\end{array}$ \\
\hline Ejigbo & 0.24 & 0.33 & 0.11 & 0.08 & 0.02 & 0.01 & 0.02 & 0.02 & 0.03 & 0.03 & 0.89 & 1 \\
\hline Ile-Ife & 0.19 & 0.35 & 0.11 & 0.07 & 0.02 & 0.01 & 0.01 & 0.01 & 0.03 & 0.03 & 0.83 & $0.352 * *$ \\
\hline Ilesa & 0.32 & 0.39 & 0.14 & 0.13 & 0.03 & 0.02 & 0.04 & 0.04 & 0.06 & 0.06 & 1.23 & $0.351 * *$ \\
\hline Iwo & 0.20 & 0.33 & 0.13 & 0.05 & 0.01 & $\mathrm{Nd}$ & $\mathrm{Nd}$ & $\mathrm{Nd}$ & 0.02 & 0.02 & 0.76 & $0.556 * *$ \\
\hline Osogbo & 0.30 & 0.41 & 0.14 & 0.09 & 0.04 & 0.02 & 0.03 & 0.03 & 0.04 & 0.04 & 1.14 & $0.591 * *$ \\
\hline Range & 0.19-0.32 & 0.33-41 & 0.11-0.14 & $0.05-0.13$ & 0.01-0.04 & Nd-0.02 & Nd-0.04 & Nd-0.03 & $0.02-0.06$ & $0.02-0.06$ & & \\
\hline Mean & 0.25 & 0.36 & 0.13 & 0.08 & 0.02 & 0.01 & 0.02 & 0.02 & 0.04 & 0.03 & & \\
\hline WHO* & 0.3 & 0.4 & 3.0 & 2 & 0.01 & 0.006 & 0.01 & 0.003 & 0.05 & 0.007 & & \\
\hline
\end{tabular}

** Correlation is significant at the 0.01 level (2-tailed)

Table 4: Mean levels $(\mu \mathrm{g} / \mathrm{mL})$ of trace metals in water sources in the areas studied

\begin{tabular}{|c|c|c|c|c|c|c|c|c|c|c|c|}
\hline & $\mathrm{Fe}$ & $\mathrm{Mn}$ & $\mathrm{Zn}$ & $\mathrm{Cu}$ & $\mathrm{Pb}$ & $\mathrm{Hg}$ & As & $\mathrm{Cd}$ & $\mathrm{Cr}$ & $\mathrm{Ni}$ & $\begin{array}{l}\text { Correlation } \\
\text { matrix }\end{array}$ \\
\hline Borehole & 0.27 & 0.37 & 0.13 & 1.0 & 0.03 & 0.01 & 0.02 & 0.02 & 0.04 & 0.04 & 1 \\
\hline Stream & 0.30 & 0.40 & 0.14 & 0.11 & 0.03 & 0.03 & 0.03 & 0.04 & 0.05 & 0.05 & $0.808 * *$ \\
\hline Tap & 0.18 & 0.33 & 0.12 & 0.05 & 0.01 & $\mathrm{Nd}$ & $\mathrm{Nd}$ & $\mathrm{Nd}$ & 0.02 & 0.02 & $0.548 * *$ \\
\hline Well & 0.25 & 0.35 & 0.11 & 0.07 & 0.02 & 0.01 & 0.02 & 0.02 & 0.03 & 0.03 & $0.952 * *$ \\
\hline WHO* & 0.3 & 0.4 & 3.0 & 2.0 & 0.01 & 0.006 & 0.01 & 0.003 & 0.05 & 0.07 & \\
\hline
\end{tabular}

** Correlation is significant at the 0.01 level (2-tailed) 


\section{References}

Adeniyi, I.F. (2004). Concept of water quality. In: Ife Environmentalist, official bulletin of Nigeria society of Environmental Management (NISEM), OAU 1 (1):2

Aiuppaa, A., Bellomoa, S., Bruscab, L., Alessandrob, W. D., Federico, C. (2003). Natural and anthropogenic factors affecting groundwater quality of an active volcano (Mt. Etna, Italy). Applied Geochemistry 18: 863-882.

Bacha, A.A., Durrani, M.I., Paracha, P.I. (2010). Chemical characteristics of drinking water of Peshawar. Pakistan Journal of Nutrition 9(10), 1017-1027

Farrell-Poe, K. (2010). Arsenic in Drinking Water Wells. Arizona Cooperative Extension, College of Agriculture and Life Sciences, University of Arizona. AZ1486k, 3pp.

Fatoki, O.S., Luyizan, O. and Ogunfowokan, A.O. (2003). Trace metal pollution in Utama River. Water South Afr., 28(2): 183-189

Goyer, R.A. and Clarkson, T.W. (2001). Toxic effects of metals. In: Klaassen, C.D. (ed) Casarett and Doull's Toxicology: The basic science poisons, $6^{\text {th }}$ Edition, McGraw-Hill Medical Pub. Division.

Grandjean, P. and Nielson, T. (1979). Organolead compounds:environmental health aspects. Residual Revs., 72: 97148.

Ibe, K.M. and Duruike, P.U. (2005) Hydrogechemical characteristics of groundwater and surface water: A case study of Isiala Mbano, Southeastern Nigeria. World Journal of Biotechnology. 2:278-286

Ince, M., Bashir, D., Oni, O.O.O., Awe, E.O., Ogbechie, V., Korve, K., Adeyinka, M.A., Olufolabo, A.A., Ofordu, F., Kehinde, M. (2010). Rapid
Assessment of Drinking Water Quality (RADWQ) in the Federal Republic of Nigeria. Country Report 2004-2005. WHO and UNICEF, 92pp. www.wssinfo.org/fileadmin/user_uploa d/resources/RADWQ_Nigeria.pdf

IPCS (1991) Nickel. Geneva. World Health Organization. International Programme on Chemical Safety (Environmental Health Criteria 108)

Keen, C.L., Ziderberg-Cherr, S. (1996). Manganese. In: Ziegler EE and Filler LJ Jr (Eds) Present Knowledge in Nutrition, Washington, D.C. pp. 334343.

Michael, F.L., Standford, J. (2003). Epidemological Investigation, Fred Hutchison Cancer Research Centre and National Cancer Institute, Bethseda.

Nsi, E.W. and Ogori, B.O. (2005) A survey of water quality in some areas of Makurdi. International Journal of Science and Technology, 2: 7-11

Okunola, O.J., Uzairu, A., Ndukwe, G.I. and Adewusi, S.G. (2011). Geochemical portioning of heavy metals in roadside surface soil of different grain size major roads in Kano metropolis, Nigeria. British Journal of Applied Science and Technology, 1:94-115

Olutona, G.O., Aribisala, O.G., Akintunde, E.A. and Obimakinde, S.O. (2012). Chemical speciation and distribution of trace metal in roadside soil from major roads in Iwo, a semi-urban city, south western Nigeria. Terrestrial and Aquatic Environmental Toxicology, .6 (2): 116-126

Oluyemi, E.A. Adekunle, A.S., Adenuga, A.A. and Makinde, W.O. (2010). Physico-chemical properties and heavy metal content of water sources in Ife North Local Government Area of Osun State, Nigeria. African Journal of 
Environmental Science and Technology, 4:691-697

Oyeku, O.T. and Eludoyin, A.O. (2010). Heavy metal contamination of groundwater resources in Nigerian urban settlements. African Journal of Environmental Science and Technology, 4: 201-214.

Oyekunle, J.A.O., Okpu, R.C., Ogunfowokan, A.O., Olutona, G.O. and Durosinmi, L.M. (2012). Total and exchangeable metals in groundwater of Ile-Ife, Southwestern Nigeria. Hydrology for disaster management Special Publication of the Nigeria Association of Hydrological Sciences, 208-223

Patil, G. and Ahmad, I. (2011). Heavy metal contamination assessment of Kanhargaon dam water near Chhindwara City. Acta Chim. Pharm. Indica. 1(1): 7-9

Rafati, L., Mahvi, A.H., Asgari, A.R. and Hosseini, S.S. (2010). Removal of chrominum (VI) from aqueous solutions using Lewatit FO36 nano ion exchange resin. International Journal of Environmental Science and

Technology, 7(1):147-156

Robert, C. (2008). Editor's log: underground construction magazine. Oildom Publishing Company, Texas, USA. 63:2

Schwartz, M.K. (1975). Role of trace element in cancer. Cancer Research 35, 3481

Van der Merwe, D., Carpenter, J.W., Nietfeld, J.C. and Meisner, J.F. (2011).
Adverse effect in Canade geese (Branta Canadensis) associated with waste from zinc and lead mines in the Tri-State Mining district, Kansas, Oklahoma and Missouri, united State of America Journal of Wildlife, 47(3): 650-660.

WHO (2004). Water, Sanitation and Hygiene links to Health. Facts and Figures. http://www.who.int/water_sanitation_h ealth/facts2004/en/

WHO (2005a). Mercury in drinking water. Background document for development of WHO guideline for drinking water quality. WHO/SDE/WSH/05.08/10. $18 \mathrm{pp}$.

http://www.who.int/water_sanitation_h ealth/dwq/chemicals/mercuryfinal.pdf

WHO (2005b). Nickel in drinking water. Background document for development of WHO guideline for drinking water quality. WHO/SDE/WSH/05.08/55. 30pp

WHO (2011). World Health Organization. Guidelines for drinking water quality. $4^{\text {th }}$ Edition. WHO Press, Geneva. pp 564

Wordstron, J.W. (1982). Trace element nutrition in the elderly. Am. J. Clin. Nutr. 36:788-795

$\mathrm{Wu}, \mathrm{T}$., Germaine, M.B. and Menddola, P. (2003). Blood lead levels and sexual maturation in US girls: The $3^{\text {rd }}$ National health and nutrition examination survey, 1988-1994. Environ. Health Prospect, 111: 737-741. (www.lenntech.com/heavymetals.htlm) 